\title{
Regulação social e acumulação por espoliação - reflexão sobre a essencialidade das teses da financeirização e da natureza do Estado na caracterização do capitalismo contemporâneo ${ }^{1}$

\author{
Niemeyer Almeida Filho ${ }^{2}$ \\ Leda Maria Paulani ${ }^{3}$
}

\begin{abstract}
Resumo
O artigo estrutura-se a partir da interpretação da natureza do capitalismo contemporâneo de David Harvey, particularmente de sua proposição de que esta natureza é essencialmente espoliadora. Esta proposição é confrontada e qualificada pelas teses da financeirização expressas na contribuição de François Chesnais. Daí em diante, mostra-se como a discussão do Estado, de sua forma de operação, sobretudo de suas funções de regulação social, introduz elementos essenciais do "campo político" na caracterização do capitalismo contemporâneo. Neste particular, incorporam-se elementos teóricos de Joachim Hirsch, relativos ao processo de regulação social, mostrando que, para ele, há um "sistema de regulação social" diversificado, que torna o tema da regulação bem mais complexo do que usualmente se reconhece. O artigo busca, assim, mostrar que a associação entre as teses da regulação social e da acumulação por espoliação pode ampliar o escopo de caracterização do processo social de reprodução no capitalismo de hoje, bem como a análise de suas condições de superar as crises.
\end{abstract}

Palavras-chave: Acumulação por espoliação; Regulação social; Capitalismo contemporâneo.

\begin{abstract}
Social regulation and accumulation by spoliation - reflection on the essence of the theses of financialization and the nature of the state in the characterization of contemporary capitalism

The article is structured from David Harvey`s interpretation of the nature of contemporary capitalism, particularly his proposal that this nature is essentially predatory. This proposition is confronted and qualified by the theses of financialization expressed in the contribution by François Chesnais. Thereafter it is shown how the discussion of the State, its mode of operation, especially its functions of social regulation, introduces key elements of "politics fields" in the characterization of contemporary capitalism. In doing so, there is an incorporation of theoretical elements of Joachim Hirsch, concerning the process of social regulation, showing that for him there is a "system of social regulation" diversified, which makes the issue of regulation more complex than usually recognized. The article thus seeks to show that the association between the theories of social regulation and
\end{abstract}

(1) Trabalho recebido em 28 de março de 2008 e aprovado em 18 de novembro de 2009.

(2) Professor Associado do Instituto de Economia da Universidade Federal de Uberlândia (UFU), Uberlândia, MG, Brasil. E-mail: nafilho@ufu.br. O autor agradece o apoio do Procad-Capes, que permitiu a realização de um estágio de pós-doutoramento no Departamento de Economia da FEA-USP (Faculdade de Economia, Administração e Contabilidade da Universidade de São Paulo) em 2007/2008 sob a supervisão da professora Leda Maria Paulani. Este artigo cumpre os requisitos necessários à obtenção do certificado de conclusão da pesquisa.

(3) Professora Titular do Departamento de Economia da FEA-USP e do programa de pós-graduação em Economia do FEA/USP, São Paulo, SP, Brasil. E-mail: paulani@usp.br.

Economia e Sociedade, Campinas, v. 20, n. 2 (42), p. 243-272, ago. 2011. 
accumulation by dispossession can broaden the scope of characterizing the process of social reproduction in capitalism today, as well as the analysis of their conditions to overcome the crisis.

Keywords: Accumulation by spoliation; social regulation; contemporary capitalism JEL B5, O1, P1.

\section{Introdução}

Em seu livro O novo imperialismo, publicado em 2003 (tradução brasileira em 2004), David Harvey cunha um conceito que vem se difundindo, no campo crítico, na caracterização do capitalismo contemporâneo. A "acumulação por espoliação" consiste numa persistente e recorrente prática predatória de "acumulação primitiva", que Harvey considera, na trilha de Rosa Luxemburgo, como tendo caráter permanente. O conceito de acumulação por espoliação é formulado a partir da exposição da natureza do capitalismo que Harvey faz em seu livro teórico de maior fôlego: The limits to capital (1982). Nele, o processo de desenvolvimento capitalista e, assim, a reprodução da ordem social, são apreendidos pela relação contraditória das lógicas do território e do capital, considerando que, em todo momento histórico-geográfico dado, uma ou outra dessas lógicas pode predominar.

É na lógica do território que se apresenta mais claramente o imperialismo. No capitalismo, sobretudo no período histórico que se inicia com a constituição dos Estados nacionais, as ações imperialistas são identificadas como ações de Estado ou conjuntos de Estados, embora tenham uma forte relação com os interesses diretos moleculares do capital (das unidades de capital no plano da concorrência).

No âmbito do imperialismo stricto sensu, a busca de territórios e a imposição de controles sobre eles atuam como um fim em si, apesar de terem consequências inequivocamente econômicas (no plano da extração de tributos, dos fluxos de capital e trabalho etc.). Mas, segundo o autor, "o quadro se altera substancialmente numa situação em que o controle territorial (que pode ou não envolver a apropriação e a administração concretas de territórios) é considerado um meio necessário da acumulação de capital. $\mathrm{O}$ que distingue o imperialismo capitalista de outras concepções de império é que nele predomina tipicamente a lógica capitalista, embora haja momentos em que a lógica territorial venha em primeiro lugar" (Harvey, 2004, p. 36). Com base nesta formulação, Harvey sugere a proposição de que há uma atribuição "virtualmente indispensável" ao Estado capitalista no processo de acumulação. O "virtualmente indispensável" tem que ver com a característica de que os processos moleculares de acumulação de capital podem criar de inúmeras maneiras suas próprias estruturas de operação no espaço, suas próprias "regionalidades", produzindo complexas redes de atividades independentes do poder do Estado.

Ao formular o processo de reprodução da sociedade capitalista dessa forma, Harvey está, aparentemente, tratando do que outras vertentes do marxismo 
chamam de "regulação social". Arenti (2006) mostra como as proposições de Aglietta (1979) inauguram um novo caminho de investigação da trajetória das economias capitalistas. Acumulação e crise passam a ser estudadas conjuntamente, com a preocupação de analisar como as economias capitalistas mantêm a acumulação de capital e lidam com as crises que são inerentes ao capitalismo.

Há, assim, um esforço em explicar a dinâmica das economias capitalistas não apenas como reprodução de relações e estruturas básicas, mas também, e talvez principalmente, como um processo no qual as transformações estruturais que sustentam cada nova fase do processo de acumulação superam temporariamente suas crises. As referências principais sobre este tipo de visão estão nas abordagens regulacionistas, em suas diversas vertentes ${ }^{4}$.

Essa perspectiva trata teoricamente o Estado como uma instituição que tem funções bem definidas no processo de regulação, sendo que a principal delas está relacionada com a garantia do dinheiro, especialmente num período histórico em que não está mais em vigência a referência deste a uma mercadoria produzida pelo trabalho, e no qual há uma multiplicidade de "dinheiros" nacionais em circulação. Com isso, o papel do Estado relaciona-se primordialmente com o monitoramento das taxas de câmbio e dos fluxos monetários externos, constituindo tais operações a parte mais expressiva daquilo que hoje se denomina política macroeconômica.

Talvez por isso, as "visões regulacionistas" atribuam ao Estado uma responsabilidade substantiva na regulação da economia, sobretudo em períodos de crise ${ }^{5}$. Joachim Hirsch ([1994] 2007), ao fazer uma avaliação crítica da Escola da

(4) A diferenciação das diversas abordagens regulacionistas não está dentro dos nossos propósitos neste artigo. Em Jessop (1990), texto de referência sobre o tema da regulação, há a identificação de sete escolas e quatro tipos de perspectivas. As escolas são as três francesas (Groupe de Recherche sur la Régulacion d'Economies Capitalistes - GRREC; os Regulacionistas Parisienses; e os Regulacionistas do PCF), a escola norte-americana, a escola alemã-ocidental, a escola de Amsterdã e a escola nórdica. Os quatro tipos de perspectivas advêm, para cada escola, da apreensão conjunta de quatro dimensões: a nacional, a internacional, o foco econômico e o foco na socialização.

(5) Esta é uma afirmação que merece ser qualificada. Em Boyer ([1986]1990), por exemplo, onde há uma síntese tanto das ideias iniciais quanto dos aspectos teóricos ainda em desenvolvimento quando dessa publicação, fica claro que, nessa visão, não há teoricamente uma atribuição ao Estado de um "papel regulador" por excelência. Ao contrário, segundo ele o que unifica as diversas posições dos regulacionistas é uma concepção "[de] regulação como conjunção dos mecanismos que promovem a reprodução geral, tendo em vista as estruturas econômicas e as formas sociais vigentes.“ (Boyer, 1990, p. 46). Esta é uma concepção que se assemelha à de Hirsch, embora seja menos desenvolvida. Contudo, ao longo do livro e através de citações de contribuições teóricas à Escola da Regulação, fica claro que rapidamente houve um deslocamento do esforço de avançar a teoria para uma disputa em torno das proposições diretamente relacionadas à política econômica, sobretudo no começo dos anos 1980 quando a crise dos anos 1970 se agudiza. Sugerimos que advém desse "desvio" o fato de, nessas análises, o Estado acabar sendo guarnecido, através da política econômica, de uma importância decisiva, particularmente nas reflexões em torno das situações nacionais. Exemplos desses esforços, todos dessa época, podem ser encontrados em Aglietta (1986); Aglietta, Orléan e Oudiz (1980); Boyer (1980); Lipietz (1979, 1983). Para nós, basta constatar que as ações que decorrem da teoria são de política econômica e estão centradas no Estado. 
Regulação Francesa, vai considerar que, ao mesmo tempo em que há aí um déficit de teoria sobre o Estado (que ele credita às raízes althusserianas dessa escola), há também uma valorização excessiva de seu poder. Assim, apesar de seu mérito em trabalhar com um conceito ampliado de economia, que leva em conta de modo sistemático a inserção social dos processos econômicos, há, em seu entender, uma recusa dessa escola em encarar de frente uma característica chave do sistema, qual seja a autonomização dos processos econômicos que a forma valor implica. A crítica dá ensejo a uma avaliação do debate histórico, no âmbito do marxismo, sobre o papel da instância política e sobre as concepções de Estado. Daí resulta uma síntese do que poderia ser a concepção contemporânea de Estado, sendo que, para Hirsch, há um sistema de regulação mais amplo que o Estado (2007, p. 53).

Parece-nos que o tema da regulação, nos termos sintetizados acima, em conjunto com as observações de Hirsch, qualificam a formulação de Harvey. Partindo do suposto de que essas diferentes visões possuem em comum uma forte base marxiana, ainda que com ênfases e preocupações distintas, este artigo pretende indicar, a partir de uma análise dos diversos aspectos até aqui sublinhados, os pontos em que há compatibilidade e/ou complementaridade entre elas, de modo a sugerir uma caracterização da natureza contemporânea do capitalismo, ou, pelo menos, de alguns de seus elementos-chave ${ }^{6}$.

Além desta introdução, o artigo está composto por três seções. Na primeira seção discutimos a formulação da financeirização proposta por François Chesnais - na medida em que esta sua concepção assenta-se nos conceitos cunhados pela Escola Francesa da Regulação - e como ela, a nosso ver, pode ser subsumida na formulação de David Harvey. Na segunda seção, tratamos da concepção de Estado de Joachim Hirsch e de suas implicações para o desenho do capitalismo contemporâneo, confrontando-a com as de Antonio Gramsci e Claus Offe, outros dois autores que tratam do Estado, tendo a visão marxiana como ponto de partida. Na terceira seção, fazemos um esforço de síntese no sentido indicado.

\section{Finança e acumulação por espoliação}

François Chesnais vem se constituindo em uma liderança intelectual no campo do marxismo desde o lançamento de seu livro A Mundialização do Capital em 1994 (tradução brasileira em 1996). Na sequência desta obra, ele organizou, dentre diversos outros trabalhos, duas coletâneas de artigos em que suas ideias são desenvolvidas, detalhadas e acrescidas por contribuições de outros pesquisadores ${ }^{7}$.

(6) O esforço aqui desenvolvido se alinha com aquele de Moishe Postone, que, em trabalho recente ([2007] 2008), empreende uma revisão crítica das visões de Robert Brenner, de Giovanni Arrighi e do próprio David Harvey a respeito da natureza e das perspectivas do capitalismo contemporâneo.

(7) As duas coletâneas referidas ganharam edições no Brasil. São elas: A mundialização financeira, 1998 (edição francesa em 1996) e Finança mundializada, 2005 (edição francesa em 2004). 
Dessas referências bibliográficas apreende-se uma formulação sobre a natureza do capitalismo contemporâneo, que pode ser sintetizada em dois conceitos chaves: "financeirização" e "capitalismo patrimonialista".

Partindo dos conceitos básicos da teoria da regulação - "regime de acumulação" e "modo de regulação" -, Chesnais entende que o mundo contemporâneo apresenta uma configuração específica do capitalismo, na qual o capital portador de juros está situado no centro das relações econômicas e sociais. A afirmação não altera a importância anteriormente conferida por ele ([1994]1996) aos grupos transnacionais, que continuam atuando como unidades de capital visíveis. Esses grupos mantêm (ou ampliam) o controle sobre a produção global, sobretudo a industrial, mais sofisticada tecnologicamente, e sobre os fluxos internacionais de produtos e serviços produtivos. Contudo, a referência mais importante é para as instituições financeiras e, entre essas, especialmente as não bancárias, que seriam "constitutivas de um capital com traços particulares"10. Sustenta ele que este tipo de capital é hegemônico, determinando (ou configurando) um "novo capitalismo".

A proposição tem densidade teórica, exigindo desenvolvimento. $\mathrm{O}$ aspecto chave está na compreensão desse tipo específico de capital, o capital portador de juros (ou o "capital financeiro", ou simplesmente a "finança"). A hegemonia desta forma de capital é produto de condições históricas, particularmente das mudanças no alcance da regulação feita pelo Estado. Para Chesnais, foi necessário que os "Estados desenvolvidos" decidissem liberar o movimento dos capitais, desregulamentar e desbloquear seus sistemas financeiros nacionais, além de adotar políticas de favorecimento da centralização dos fundos líquidos não reinvestidos das empresas e das poupanças das famílias para que essa hegemonia se estabelecesse.

Nas condições históricas em que tais mudanças se efetivaram, as unidades de capital que se especializaram na "acumulação pela via da finança" tornaram-se,

(8) Para uma posição contrária às teses da financeirização, particularmente às posições de Chesnais, veja-se Prado (2005).

(9) "Regime de Acumulação" (RA) e "Modo de Regulação" (MR) são conceitos concebidos a partir do conceito marxiano de "modo de produção". A ideia básica é que, apesar de a lógica capitalista (a busca da valorização do valor) estar sempre presente, a forma como ela se efetiva pode ser diferente em cada momento histórico, dadas as diferentes formas e figuras assumidas pelo capital em seu movimento. Daí que RA é definido como o conjunto das regularidades econômicas e sociais que, num dado momento histórico, garantem, no longo prazo, a acumulação, enquanto que MR é definido como o conjunto de procedimentos capaz de sustentar e pilotar o RA em vigor, reproduzir as relações fundamentais através de formas institucionais historicamente determinadas e garantir a compatibilidade de decisões descentralizadas, sem que seja necessária a interiorização dos princípios de ajustamento do sistema por parte dos atores econômicos (Boyer, 1990).

(10) Vale lembrar que, no Brasil, bem antes disso - como vimos, o primeiro trabalho de Chesnais sobre a financeirização é de 1996 - Braga (1985), ainda que não com o mesmo referencial teórico, também apontara essa proeminência da valorização financeira no capitalismo pós-1970. 
através dos mercados bursáteis, proprietárias dos grupos empresariais mais importantes em nível global. Desta maneira, impuseram à própria acumulação de capital produtivo uma dinâmica orientada pela maximização do "valor acionário". Neste sentido, há uma superposição de movimentos de acumulação, sendo o primeiro e mais tradicional orientado pelo controle da acumulação produtiva; e o segundo, dominante, orientado pela dimensão relativamente muito maior e crescente das finanças. As instituições especializadas a que se refere Chesnais são os "investidores institucionais" (fundos de pensão, fundos coletivos de aplicação, sociedades de seguros, bancos que administram sociedades de investimentos, fundos de hedge), que lograram realizar a centralização da "finança".

Em Chesnais (2005) há desenvolvimento amplo do que foi sinteticamente apresentado acima assim como uma apreensão factual que sustenta essa análise. É a partir desta apreensão que ele identifica diferentes formas de financiamento que configuram o campo da "finança" e definem a natureza contemporânea da "propriedade patrimonial" capitalista. Esta seria dominada pela figura do proprietário acionista, pelo possuidor de títulos de empresas e pelos proprietários de títulos da dívida pública. A tese é que os detentores das ações e títulos privados de débito e de volumes importantes de títulos públicos são efetivamente proprietários situados numa posição de exterioridade à produção, e não "credores", como normalmente se caracteriza. Isto quer dizer que esses proprietários pressionam para que a valorização de seus ativos seja a maior possível e para que os lucros sejam os mais altos no curto prazo, relegando a segundo plano a visão estratégica dos negócios, que privilegia a maximização de longo prazo. A tese é remetida a Aglietta (1998), que sustenta que o regime de acumulação contemporâneo, ao menos como ele existe nos EUA, é essencialmente "patrimonial". Em outras palavras, significa uma posição de proeminência do "proprietário", numa inversão do que foi historicamente tratado como separação entre propriedade e controle ${ }^{11}$.

Essa proeminência da propriedade remete à distinção entre finanças intermediadas, que caracterizariam o regime de acumulação anterior (de 1945 a meados dos anos 1970), e finanças diretas, que, para Chesnais, caracterizam o regime atual. Para ele, o termo "credor" remete a "empréstimo" e a um papel das finanças que é, em última instância, o de direcionar as poupanças para quem deseja investir. Mas a finança atual não é, como essa, movida pelas necessidades da produção e da criação de riqueza nova. Sua instituição central é o mercado secundário de títulos, que só negocia ativos já emitidos e possibilita a valorização fictícia da propriedade já existente. A difusão desse tipo de mercado faz com que os aplicadores de recursos jamais conheçam quem são seus devedores, não thes

(11) Para um tratamento recente da temática originária veja-se Mizruchi (2004). 
importando "[saber] 'quem pagará o mico', mas saber se os mercados permanecerão líquidos” (Chesnais, 2005, p. 49).

Nesse sentido, poder-se-ia acrescentar que o movimento mais tradicionalmente reconhecido como sendo de acumulação envolve os fluxos de renda (e de valor) da economia, enquanto que a acumulação financeira, comandada pelos mercados secundários, relaciona-se predominantemente aos estoques de riqueza. Contudo, o elemento mais importante da tese afirmada por Chesnais quanto à natureza financeirizada do capitalismo de hoje não se prende a essa distinção (fluxos de renda x estoques de riqueza), mas coloca na base do argumento o caráter de exteriorização em relação à produção dos ganhos proporcionados pelas finanças (mesmo que eles sejam provenientes, por exemplo, de dividendos, estando relacionados, portanto, aos fluxos de renda).

A propriedade patrimonial cria direitos a rendimentos sob a forma de aluguéis, de rendas do solo, de juros e de fluxos relacionados às aplicações em Bolsa, provenham eles de dividendos, de mais-valias bursáteis ou da especulação (antecipação de ganhos que nascem da variação de preços). Assim, o sentido mais profundo da formulação de Chesnais está em tomar o "capitalismo patrimonial" como sendo inteiramente direcionado para transformar o dinheiro, de "ativo líquido", em um valor que "produz", donde a recuperação que ele faz da afirmação de Marx segundo a qual "o voto piedoso do entesourador se encontra realizado no capital portador de juros, pois suas economias adquirem a propriedade de proporcionar rendimentos tão naturalmente como a pereira dá peras" (Chesnais, 2005 , p. 50). Evidentemente nada disso é novo no capitalismo e existiu sempre, em maior ou menor medida, em cada uma das fases de seu desenvolvimento histórico. O que Chesnais destaca como sendo novo é o protagonismo que a propriedade e o rentismo assumiram bem como o alojamento dessa posição de exterioridade à produção no seio da própria produção ${ }^{12}$.

No nível da macroestrutura - a macroeconomia mundial -, isto implicaria o desenho de uma configuração do capitalismo global marcada pela dominação econômica e social do capital portador de juros, com suas contradições e impasses típicos. Isto não significa, lembra Chesnais, afirmar que estejam superadas ou tenham menor importância as contradições basilares do sistema, fundadas na propriedade privada dos meios de produção e na imposição à maioria da população da necessidade de vender sua força de trabalho. Mas essa patologia congênita combina-se agora com as contradições e os processos antagônicos

(12) Para Chesnais o fortalecimento das finanças teve dois resultados importantes: a enorme força do processo de centralização de capitais tanto nacional quanto internacionalmente e o fato de que "... a finança conseguiu alojar a exterioridade da produção no próprio cerne dos grupos industriais" e ela fez isso substituindo o administrador industrial pelo administrador financeiro, cujo comportamento é pautado "pela tendência da Bolsa, mais do que por qualquer outra coisa“ $(2005$, p. 54$)$. 
suplementares cuja origem é, de um lado, uma acumulação branda e, de outro, o que, por hipótese, é chamado de "insaciabilidade" da finança quanto ao nível de suas punções.

A propensão do capital portador de juros para demandar da economia 'mais do que ela pode dar' é uma consequência de sua exterioridade à produção. É uma das forças motrizes da desregulamentação do trabalho, assim como das privatizações. Mas ela tende, também, a modelar a sociedade contemporânea no conjunto de suas determinações (Chesnais, 2005, p. 61).

Evidentemente, não se pode deixar de reconhecer a força da análise teórica de Chesnais, sobretudo porque ela vem acompanhada de análise factual realizada por um conjunto significativo de reconhecidos pesquisadores. Contudo, apesar de, segundo a escola francesa da regulação, a forma de organização do Estado ser uma das cinco formas institucionais constituidoras do "modo de regulação social"", não se encontra em seu trabalho, nem nos de seus companheiros de coletâneas, uma análise mais focada sobre o papel do Estado e o papel da instância política neste regime de acumulação comandado pela finança. Parece-nos, por isso, que esta base factual pode ser relida (ou subsumida) pela formulação de David Harvey, que, apesar de não usar o termo "regulação", trabalha em chave similar, com a vantagem de discutir diretamente o papel do Estado nessa nova etapa da história capitalista.

Diferentemente de Chesnais, para analisar as transformações experimentadas pelo capitalismo contemporâneo, Harvey, em A condição pósmoderna (publicado em 1989, tradução brasileira em 1992), toma como ponto de partida um referencial mais amplo do que o estritamente econômico. Tendo por apoio a análise teórica desenvolvida alguns anos antes em Limits to capital, ele vai defender, no trabalho de 1989, a tese de que, desde os anos 1970, estariam ocorrendo mudanças expressivas nas práticas culturais bem como políticoeconômicas que estariam vinculadas à emergência de novas maneiras dominantes de experimentação do tempo e do espaço. O desenvolvimento capitalista teria engendrado uma forma nova de acumulação, com a utilização crescente e o aumento de poder das formas mais fluidas e voláteis de capital, o que estaria tendo implicações diretas nas formas de ordenação espaço-temporais ${ }^{14}$. Em outras palavras, a ascensão de formas culturais pós-modernas e a emergência de modos

(13) As outras quatro formas são: a relação de trabalho, o regime monetário e financeiro, a relação concorrencial intercapitalista e o regime internacional (as relações entre as diversas economias nacionais). Vejase a esse respeito Boyer (1990).

(14) Em função dos desenvolvimentos posteriores que faremos das considerações de Harvey, vale a pena lembrar que, para ele, as ordenações espaço-temporais são os expedientes utilizados pelo capital para enfrentar as recorrentes crises de sobreacumulação. Esses movimentos podem ser de deslocamento temporal, através de investimentos em projetos de longo prazo (em geral em infraestrutura) ou gastos sociais (como a pesquisa, por exemplo), e/ou de deslocamentos espaciais, que permitem a abertura de novos mercados e/ou de novos recursos, como, por exemplo, mão de obra a preços mais reduzidos (Harvey, 2004, p. 93-94). 
mais flexíveis de produção e acumulação estariam configurando uma nova organização do capitalismo. Nessa análise, porém, não é sistematicamente estudado o papel do Estado nesse processo geral de transformação ${ }^{15}$.

Nos trabalhos mais recentes, esse âmbito da questão é mais diretamente enfocado. Em O Novo Imperialismo é examinada a atual condição do capitalismo global e o papel que um "novo" imperialismo poderia estar aí desempenhando. A perspectiva, como ele afirma na introdução do trabalho, é da longue durée ${ }^{16}$ "formulada pelas lentes do materialismo histórico-geográfico" (Harvey, 2004, p. 11). Sua principal questão reside em saber como o poder americano se expandiu e vem se desenvolvendo no confronto das duas lógicas próprias ao desenvolvimento capitalista, quais sejam aquelas do território e do capital. Para respondê-la, ele vai inicialmente mostrar que a lógica territorial se estabelece no âmbito do "poder político", portanto, no âmbito do Estado capitalista. Esta parece ser uma novidade importante na análise de Harvey, já que a lógica do capital, incluindo a própria ocupação do espaço, é bastante tratada em outros trabalhos. Em sua introdução à edição de 2006 do The limits to capital, escreve David Harvey:

O papel do Estado na acumulação por espoliação impõe também uma mudança analítica. Limits, como eu indico no posfácio, não propõe uma teoria específica sobre o Estado capitalista, apesar de ele ser onipresente ao longo de todo o texto. Eu deixei essa questão como um "algo inacabado" (...) Mas eu acabei sendo restituído a um debate de escopo ainda mais largo (...) sobre como entender o Estado contemporâneo e seus poderes (p. xvii).

Para nosso autor, "o poder político é sempre constituído por alguma combinação instável de coerções, emulações e exercício da liderança mediante o desenvolvimento do consentimento" (Harvey, 2004, p. 43), mas, para ele, esses meios só são efetivos se se fundarem nalguma base material e Harvey vai identificar essa base material no dinheiro, na capacidade produtiva e na força militar. São esses, para ele, "os três pilares em que se apoia a hegemonia no âmbito do capitalismo. Mas também aqui estamos diante de configurações mutáveis e instáveis" (idem, ibidem).

(15) Também Postone, analisando o trabalho de Harvey de 1989, observa que, apesar de focado na questão da financeirização, ele "é menos centrado no Estado do que o de Arrighi ( $O$ longo século $X X)$, o qual é ligado à questão dos hegemons ascendentes e declinantes“ ([2007] 2008, p. 92). A perspectiva de $O$ novo imperialismo, a cuja análise daremos aqui prioridade por conta de sua apresentação do conceito de "acumulação por espoliação“, vai cobrir justamente essa lacuna. Postone observa, no entanto, que sua abordagem da relação entre cultura e capitalismo, por vincular intrinsecamente as formas culturais com uma configuração de larga escala do capitalismo, vai além da Teoria da Regulação, que se limitaria a uma análise funcionalista das primeiras para com a segunda (idem, p. 93).

(16) O termo, como se sabe, pertence à chamada Escola dos Anais, influente abordagem francesa da historiografia, que põe o acento da análise nos elementos que permitem a manutenção das estruturas e a reprodução da sociedade, mais do que nos eventos pontuais que acabam por constituir sua história. Iniciada no final dos anos 1920, essa escola teve em Fernand Braudel um de seus membros mais destacados. 
A partir desses princípios, Harvey faz uma análise histórica, dividindo o período dos "imperialismos capitalistas" em três etapas. Na primeira delas, descreve a ascensão dos "imperialismos burgueses", no período de 1870 a 1945 (período de consolidação do poder político burguês nos Estados europeus, reorientando a política territorial de modo a adequá-la aos requisitos da lógica capitalista).

A segunda etapa é a do pós-Segunda Guerra Mundial até os anos 1970, ou a do período conhecido como "os anos dourados do capitalismo". A ênfase aqui é colocada na hegemonia norte-americana sobre o bloco capitalista e no exercício do poder político. Segundo Harvey, os Estados Unidos puseram-se à frente dos acordos de segurança coletiva usando as Nações Unidas e, particularmente relevante, usando alianças militares como a OTAN (Organização do Tratado do Atlântico Norte) a fim de limitar a possibilidade de guerras intercapitalistas e combater a influência da União Soviética e, mais tarde, da China. Além de apoiar a derrubada de governos democraticamente eleitos (os casos citados por ele são Irã, Guatemala, Brasil, Congo, República Dominicana, Indonésia e Chile), os Estados Unidos buscaram construir uma ordem internacional aberta ao comércio e ao desenvolvimento econômico, propiciando uma rápida expansão da acumulação capitalista.

Ao tornar-se a nação imperialista no pós-Segunda Guerra Mundial, os Estados Unidos teriam se tornado também a referência civilizatória do mundo capitalista, desautorizando formalmente o racismo, o qual, segundo Harvey permitira a reconciliação do nacionalismo com o imperialismo na etapa anterior: "a Declaração dos Direitos Humanos da ONU e vários estudos da Unesco negaram validade ao racismo e buscaram fundar um universalismo de propriedade privada $\mathrm{e}$ dos direitos individuais apropriado a uma segunda etapa do regime político burguês" (Harvey, 2004, p. 53). Para dar concretude a tudo isto, os Estados Unidos constituíram-se como o bastião dos direitos individuais e projetaram no exterior o pró-americanismo, com ataque cultural aos valores europeus "decadentes" e a promoção da superioridade dos "valores americanos". Por outro lado, os Estados Unidos passaram a ser vistos como o principal motor da acumulação de capital, capaz de liderar e arrastar o resto do mundo. Para Harvey, o Estado norteamericano tornou-se nesses anos um Estado "desenvolvimentista" com enormes quantidades de capital aplicadas em serviços públicos, infraestrutura e desenvolvimento regional, e essas transformações internas da economia americana assumiram enorme importância global graças às oportunidades de mercado que $\operatorname{propiciaram}^{17}$.

(17) As aspas em 'desenvolvimentista' justificam-se porque o termo é usualmente aplicado às economias menos desenvolvidas que, no mesmo período, tiveram no Estado o esteio de seu processo de acumulação de capital (que tinha que andar mais rápido do que aquele dos países centrais). 
Ainda segundo Harvey, essa etapa termina nos anos 1970, por diversas razões, sendo a primeira delas a abrangência excessiva, já que a confrontação com o comunismo colocou os gastos militares em níveis muito elevados, sobretudo no período da Guerra do Vietnã. O resultado foi uma crise fiscal do Estado no interior dos Estados Unidos e a resposta imediata foi o uso da primazia de ser o país detentor da moeda internacional, com expansão das emissões de dólar para além das necessidades do crescimento da economia global. A consequência foi o detonamento de pressões inflacionárias mundiais, que vêm a constituir as condições genéticas para a explosão de capital "fictício" ora em circulação, e o colapso das estruturas internacionais que eram a base do superimperialismo americano (OTAN, ONU).

A terceira etapa é, portanto, a da hegemonia do neoliberal, que se inicia nos anos 1970 e estaria em vigência até hoje. Ela configura-se a partir do descolamento do dólar de qualquer referência material, além do descomprometimento das economias com uma institucionalidade supervisionada. Aqui, Harvey faz uma descrição do que crê serem os fatos históricos fundamentais de afirmação do neoliberalismo como visão de mundo, sempre abrangendo as duas vertentes do capital e do território, mediadas pelo poder político do Estado. Ameaçados no campo da produção, os Estados Unidos passam a exercitar a sua hegemonia por meio das finanças, o que exigiu que os mercados em geral, e os mercados de capital em particular, se abrissem internacionalmente. Este foi um processo lento e de intensa pressão dos Estados Unidos. Utilizando-se das instituições multilaterais, particularmente FMI e Banco Mundial, o Estado americano foi capaz de impor ao mundo uma nova ortodoxia econômica, que evidentemente envolveu a passagem do equilíbrio do poder e de interesses da burguesia de atividades produtivas para instituições vinculadas ao capital financeiro ${ }^{18}$.

Não nos parece necessária a recuperação integral da análise histórica desse período feita por Harvey, pois ela não difere essencialmente daquelas de outros autores marxistas. Vale a reiteração de que as crises que se sucedem têm sempre, para ele, natureza de sobreacumulação, argumento que está no centro, por exemplo, da tese defendida por Brenner ([2002] 2003) ${ }^{19}$. O que difere de outras

(18) Sobre isso afirma Harvey: “... os interesses financeiros norte-americanos não se importaram nem um pouco em solapar a hegemonia dos Estados Unidos na produção. Esse sistema chegou ao apogeu nos anos Clinton, em que o Departamento do Tesouro, gestão Rubin-Summers, orquestrou os negócios internacionais a fim de dar grandes vantagens aos interesses rentistas de Wall Street, ainda que correndo com frequência grandes riscos para fazê-lo“ (2004, p. 152).

(19) Apesar de Harvey referir-se ao livro o Boom e a Bolha, de 2002 (tradução brasileira em 2003), onde Brenner retoma essa tese, é em trabalho anterior, The economics of global turbulence, de 1998, que ele a desenvolve integralmente. 
análises é a consideração do poder político como espaço primordial na ação da burguesia.

Nessa perspectiva, é nos capítulos 3 e 4 de $O$ novo imperialismo que Harvey vai apresentar os dois elementos fundamentais de sua análise do capitalismo contemporâneo. O primeiro trata do poder político, mostrando a relação entre o mesmo e a acumulação de capital, enquanto o segundo trata da "acumulação por espoliação", ou da natureza permanente do capitalismo de demandar "acumulação primitiva".

A preocupação é tratar em duas vertentes distintas aquilo que Harvey considera ser o problema recorrente do capitalismo: a ausência de oportunidades lucrativas que deem vazão ao processo de acumulação de capital. No capítulo 3, há uma apreensão de como e através de que mecanismos a expansão geográfica e a reorganização espacial e temporal proporcionam ou pelo menos mitigam a depreciação do capital. A esse respeito diz Harvey: "A lógica capitalista (em oposição à lógica territorial) do imperialismo tem de ser entendida, afirmo eu, contra esse pano de fundo de buscar 'ordenações espaço-temporais' para o problema do capital excedente" (2004, p. 78). A questão é que a expansão geográfica envolve investimentos em infraestruturas físicas e sociais de longa duração (redes de transportes e comunicações, educação e pesquisa básica) que poderiam ser realizados pelo capital, mas que são muito mais efetivos, deste ponto de vista, quando realizados pelo Estado. Nessa perspectiva, o Estado é visto como "arcabouço territorializado no interior do qual agem os processos moleculares de acumulação de capital" (idem, p. 79).

É enquanto tal arcabouço que o Estado tem um papel decisivo no processamento da atividade capitalista:

A acumulação de capital por meio da troca de mercado fixadora de preços floresce melhor no âmbito de certas estruturas institucionais da lei, da propriedade privada, do contrato e da segurança da forma-dinheiro. Um Estado forte dotado de poderes de polícia e do monopólio dos meios de violência pode garantir tal arcabouço institucional e sustentá-lo com arranjos constitucionais definidos. A formação do Estado em associação com o surgimento da constitucionalidade burguesa têm sido, por conseguinte, características cruciais da longa geografia histórica do capitalismo. Os capitalistas não requerem absolutamente esse arcabouço para funcionar, mas na ausência dele encontram maiores riscos. Eles têm de se proteger em ambientes que podem não reconhecer ou não aceitar suas regras e maneiras de fazer negócios (...) a condição preferida para a atividade capitalista é um Estado burguês em que instituições de mercado e regras contratuais (...) sejam legalmente garantidas e em que se criem estruturas de regulação para conter conflitos de classes e arbitrar entre as reivindicações de diferentes facções do capital (2004, p. 79-80).

Assim, apesar de os processos moleculares de acumulação de capital poderem criar e criarem "as suas próprias estruturas de operação no espaço de 
inúmeras maneiras, incluindo o parentesco, as diásporas, os vínculos religiosos e étnicos e os códigos linguísticos como formas de produzir intrincadas redes espaciais de atividades capitalistas independentes das estruturas do poder do Estado" (Harvey, 2004, p. 80), o cenário mais propício e preferido para o funcionamento da atividade capitalista é aquele onde está presente a ação do Estado. Não se trata, portanto, de que a atividade capitalista seria impossível sem o Estado, mas de que ela funciona melhor com ele. Assim, para nosso autor, tão limitador quanto descrever a evolução do capitalismo como se ela fosse completamente infensa à lógica territorial do poder é considerá-la como mera expressão dos poderes do Estado no âmbito de um sistema caracterizado por lutas competitivas por posição e hegemonia.

Dessa abordagem, porém, emerge uma nova questão: se elas são por natureza opostas (fixidez x movimento, inércia x dinamismo etc.), de que forma a lógica do poder territorial, expressa na política do Estado e do império, se associa à dinâmica da acumulação do capital, com seus processos moleculares que também convergem na produção de "regionalidades"? Segundo Harvey, a resposta inicial é que essas duas lógicas não têm necessariamente qualquer relação direta uma com a outra. Por exemplo, a política de um Estado inteiro pode ser capturada pelos interesses regionais produzidos pelos processos moleculares de acumulação ou, ao contrário, espaços produzidos em função da pura lógica territorial (estradas e sistemas de comunicação construídos para fins de administração, controle militar ou proteção do território) acabam por proporcionar maior fluidez ao fluxo de bens, de trabalho e de capital, fomentando, assim, o processo de acumulação.

Como já adiantado na introdução, para Harvey, quando o controle territorial (que pode ou não envolver a apropriação concreta de territórios) já é considerado um meio necessário da acumulação, a associação entre essas duas lógicas não se dá mais aleatoriamente, mas sim sob o comando do capital. Assim, o Estado usa seus poderes para direcionar a dinâmica regional não só por meio de seu domínio dos investimentos infraestruturais e através do seu aparato administrativo, mas mediante sua atribuição de formular leis e sua capacidade de impô-las. Os exemplos vão de reformas institucionais à criação de paraísos para o investimento (2004, p. 92).

Para Harvey, a partir dos anos 1970, as ordenações espaço-temporais (deslocamentos no tempo, por meio de investimentos de longo prazo de maturação, e deslocamentos no espaço, por meio da abertura de novos mercados e novas capacidades produtivas) acabam por fracassar enquanto remédios eficientes para tratar do problema da crônica e persistente tendência à sobreacumulação que a partir daí se instaura. Por conta disso, essas ordenações que, no mais das vezes assumem uma natureza construtiva, passam a exibir um caráter destrutivo, tornando-se frequente, por exemplo, o processo de se empurrar para terras 
distantes dos pontos centrais do sistema os necessários processos de desvalorização. Esse foi, para ele, o caso das crises dos anos 80, que atingiram fundamentalmente os países da América Latina, e dos anos 90, que se espalharam por todo o conjunto dos países emergentes. É esse o contexto no qual Harvey, propõe o conceito de "acumulação por espoliação". Fazendo uma analogia com a geopolítica, ele afirma que a aliança dos poderes de Estado com os aspectos predatórios do capital financeiro gera um tipo de intervenção que está para as ordenações espaço-temporais construtivas como a guerra está para a diplomacia.

Para Harvey, assim como o sistema capitalista tem a sobreacumulação como tendência natural, ele tem também, por isso mesmo, a "acumulação primitiva", que Marx diagnostica em sua origem histórica como algo que lhe é constitutivo. Em parte, a tese recupera preocupações de Rosa Luxemburgo, sobretudo em seu livro A acumulação de capital (1985). O ponto importante é que a dinâmica da acumulação é sujeita a crises permanentes que não podem ser resolvidas apenas pela concentração e depreciação do capital, já que, neste caso, os efeitos sobre a acumulação tendem a alongar-se no tempo. Daí a ideia de que o capitalismo tem que dispor perpetuamente de algo "fora de si mesmo" para estabilizar-se. Assim, trata-se de uma incorporação da preocupação que estava por trás da análise de Luxemburgo, ainda que não propriamente do conteúdo de seu argumento (as teses subconsumistas).

O termo chave aqui é, portanto, excedente de capital. Esse excedente pode ser consumido por ordenações espaço-temporais usuais, que desembocam todas em investimentos, os quais erguem a demanda efetiva. Mas, se isso não acontece, pode se encontrar uma utilização para ele, desde que se disponha de insumos a custo muito baixo (ou zero). Nesse caso, o que a acumulação por espoliação faz é se apossar desses ativos e dar-lhes um uso lucrativo. O processo exemplar desse tipo é o da privatização. A violência que é inerente a esses movimentos tem sempre como esteio o poder de Estado, que é quem os conduz. Os outros expedientes que integram o processo de acumulação por espoliação encontram-se no sistema de crédito e no capital financeiro, pois eles permitem, entre outras coisas, dilapidação de ativos, valorizações fraudulentas, falsos esquemas de enriquecimento e o aprisionamento de populações inteiras a enormes montantes de dívidas estatais. Para Harvey, o sistema de crédito e o capital financeiro tornaramse importantes meios de predação e fraude, e o Estado, "com seu monopólio da violência e suas definições de legalidade, tem papel crucial no apoio e na promoção desses processos" (2004, p. 121).

Assim, se quando considerada simplesmente a lógica da acumulação, o Estado não aparece como necessidade para o funcionamento da atividade capitalista, ainda que ela funcione melhor com ele, quando essa lógica é a da acumulação por espoliação, o Estado passa a ter um caráter necessário, seja porque 
pode dispor de seus ativos para mitigar as crises de sobreacumulação, seja porque produz capital fictício, seja por sua atribuição de formular e impor as leis, seja finalmente porque detém o monopólio da violência.

É na centralidade conferida ao capital financeiro e aos processos de financeirização no capitalismo de hoje que encontramos o ponto de contato mais forte entre as análises de Chesnais e de Harvey. Para Harvey, essa onda, que vem desde 1973, tem sido em tudo espetacular por seu estilo especulativo e predatório, sendo que a vanguarda dessa acumulação por espoliação estaria hoje com os fundos de derivativos e outras instituições do mercado financeiro por sua capacidade de engendrar ataques especulativos (Harvey, 2004, p. 122-123). As punções e o caráter insaciável da finança aos quais se refere Chesnais não são estranhos a esta análise de Harvey, mas parecem aqui melhor qualificados, além de inseridos numa problemática mais ampla, que envolve não apenas as formas de regulação social, mas o entrelaçamento dessas formas com o poder de Estado e com as contradições da reprodução sistêmica em nível global. É essa teia argumentativa que permite relacionar a financeirização, que tão acertadamente Chesnais aponta, com a tendência do sistema de produzir crises de sobreacumulação, com a necessidade que o mesmo possui de recorrentemente mobilizar expedientes de espoliação e com o papel central do Estado nesses processos.

Portanto, há coincidência nas formulações de Chesnais e Harvey quanto à dinâmica do capitalismo contemporâneo, embora para o primeiro essa dinâmica tenha algo de inédito, enquanto que, para o segundo, a dinâmica financeirizada pode ser vista como um desdobramento histórico compatível com a natureza mesma do capitalismo, assentada na contradição entre duas lógicas, a do capital e a do espaço político (assentada na lógica territorial), além da tendência crônica do sistema a produzir crises de sobreacumulação. De qualquer forma, a ênfase de Harvey num papel ativo para o Estado nesse processo parece permitir concluir que, para ele, na etapa que se inaugura no início dos anos 1970, o Estado vai paulatinamente se organizando de modo a viabilizar a operação de diferentes expedientes de espoliação, seja por meio da abertura de novos territórios de acumulação (como nos processos de privatização), seja através da criação exacerbada de capital fictício (principalmente dívida pública), seja, finalmente, como "facilitador" dos processos de financeirização da riqueza (por conta de deter o monopólio da violência e a prerrogativa de formular leis). Em outras palavras, a atribuição "virtualmente indispensável" que Harvey confere ao Estado, muito mais do que relacionar-se a um efeito regulamentador do ambiente econômico, na ausência do qual o sistema inteiro das instituições de mercado ficaria desprovido de garantias legais, vincula-se com muito mais força, quando o processo de acumulação é tangido pela finança e pela violência da acumulação por espoliação, 
ao papel de um elemento ativo, um lócus por onde passa o processo integral de regulação social e de reprodução do capital ${ }^{20}$.

Vejamos agora como é possível enriquecer essa análise com a discussão sobre a natureza do Estado tal como colocada inicialmente por Gramsci e Offe e, depois, por Hirsch.

\section{Estado e poder político}

O tema "Estado" é controverso, não apresentando historicamente consenso teórico, mesmo no campo crítico. Em Carnoy (1988) há um apontamento que nos dá uma mostra das dificuldades teóricas.

... na medida em que as economias se desenvolveram em todo o mundo, o setor público - aqui chamado de Estado - cresceu em importância em todas as sociedades (...) e em todos os aspectos da sociedade - não apenas político, como econômico (produção, finanças, distribuição), ideológico (educação escolar, os meios de comunicação) e quanto à força legal (polícia, forças armadas). Por que isso ocorre e como se configura o crescente papel do Estado têm se tornado uma preocupação crucial para os cientistas sociais (...). O Estado parece deter a chave para o desenvolvimento econômico, para a segurança social, para a liberdade individual e, através da 'sofisticação' crescente das armas, para a própria vida e a morte. Compreender o que seja política no sistema econômico mundial de hoje é, pois, compreender o Estado nacional e compreender o Estado nacional no contexto desse sistema é compreender a dinâmica fundamental de uma sociedade (p. 9).

Para Carnoy (1988), as teorias do Estado são teorias da política e a questão crucial está em saber se a política tem alguma (ou uma grande) autonomia em relação à economia (produção, acumulação de capital), ou se simplesmente não a tem. Para os nossos propósitos de aprofundar os aspectos colocados na primeira seção, há três abordagens que nos parecem fundamentais, considerando a perspectiva de Marx como fundante ${ }^{21}$. A primeira é a concepção gramsciana, que coloca o Estado como um ponto chave para se compreender a aceitação da sociedade de classes pelas classes subalternas, sobretudo a ideia de hegemonia. A segunda é a visão de Claus Offe (1984), que argumenta que o Estado é "independente" de qualquer controle sistemático da classe capitalista, ainda que a burocracia de Estado a represente. A terceira, oriunda do debate alemão sobre o "derivacionismo", é representada pelo trabalho de Joachim Hirsch, que deduz do processo de acumulação de capital a forma e a função do Estado.

(20) Esta é certamente uma das causas do afloramento recente das teses sobre a vigência, neste estágio do capitalismo, de um estado de emergência econômico ou de um estado de exceção permanente. Ver a respeito Agamben (2004), Bercovici (2004) e Paulani (2008). Em chave um pouco distinta, Klein (2008) trata, sob perspectiva similar, da mesma temática.

(21) Evidentemente não se tem aqui a pretensão de esgotar tema tão complexo. O que se pretende é tão somente eleger e combinar algumas teorias que nos parecem fundamentais para uma interpretação das condições atuais do desenvolvimento capitalista. 
Comecemos pela abordagem de Gramsci observando, de antemão, que, evidentemente, não se trata aqui de explorar toda a riqueza de sua contribuição, muito menos de sua fortuna crítica, mas de resgatar alguns conceitos que se mostram importantes para o desenvolvimento da discussão aqui proposta. Para tanto, seguiremos, em linhas gerais, a interpretação de Carnoy (1988). Segundo esse autor, a hegemonia, que é o tema central da versão de Gramsci sobre o funcionamento do capitalismo, significa o predomínio ideológico das normas e valores burgueses sobre as demais classes, sobretudo as subalternas. Em outras palavras, o pensamento e os valores dessa classe, e mesmo seu modo de vida, são difundidos por toda a sociedade, influenciando todos os gostos e comportamentos morais, todos os costumes e relações sociais. Gramsci atribui ao Estado parte da função de promover esse conceito único da realidade, um papel, portanto, essencial no domínio da classe hegemônica. Os "aparelhos ideológicos" do Estado são, por isso, mais importantes na reprodução social do que o aparelho repressivo, derivado do monopólio da força.

Segundo o próprio Gramsci,

O exercício 'normal' da hegemonia, no terreno tornado clássico do regime parlamentar, caracteriza-se pela combinação da força e do consenso, que se equilibram de modo variado, sem que a força suplante em muito o consenso, mas, ao contrário, tentando fazer com que a força pareça apoiada no consenso da maioria... (1932-34/2000, Caderno 13, §37, p. 95).

Nesse contexto, Gramsci utiliza um conceito de sociedade civil próprio e que consiste, segundo Carnoy, em sua maior inovação teórica. Segundo este autor, tanto para Marx quanto para Gramsci, a sociedade civil é o fator chave na compreensão do desenvolvimento capitalista, mas, se para o primeiro ela faz parte da estrutura da sociedade, já que é a portadora das relações de produção, para Gramsci, ao contrário, ela integra a superestrutura, de modo que assim "... o complexo das relações ideológicas e culturais, a vida espiritual e intelectual, e a expressão política dessas relações torna-se o centro da análise, e não a estrutura." (Carnoy, 1988, p. 93).

Carnoy concorda com Norberto Bobbio quando este afirma que Gramsci inverte a teoria marxista tradicional em dois aspectos, ao enfatizar a supremacia das superestruturas ideológicas sobre a estrutura econômica e ao enfatizar a supremacia da sociedade civil sobre a sociedade política. Assim, na interpretação gramsciana, o Estado, enquanto elemento da superestrutura, torna-se variável essencial na compreensão da sociedade capitalista. Com sua dupla face, de sociedade política (porque detém o monopólio da força) e sociedade civil (graças a seus aparelhos ideológicos promotores do consenso), o conceito de Estado que daí deriva é mais amplo que o marxista-lenista, que o tomava apenas como instrumento coercitivo da burguesia. Comentando em seus Cadernos do cárcere 
um livro de Daniel Halévy, que, apesar de definir o Estado como o "aparelho representativo", descobre que os fatos mais importantes da história francesa desde o final do século XIX se devem não a iniciativas de organismos stricto sensu políticos, mas de organismos privados (entre eles empresas capitalistas e o Estadomaior) e de grandes funcionários desconhecidos do país, afirma Gramsci: "Mas isto significa que por 'Estado' deve-se entender, além do aparelho de governo, também o aparelho 'privado' de hegemonia, ou sociedade civil"' (1930-32/2000, Caderno 6, §137, p. 254).

Assim, é a ênfase na influência da superestrutura, assim como a concepção de que o Estado inclui a própria sociedade civil que habilitou Gramsci a explicar como o capitalismo era capaz, apesar do desenvolvimento de movimentos revolucionários, de manter aceitação junto a uma parcela tão significativa da classe trabalhadora (Carnoy, 1988, p. 116-117). Gramsci teria percebido que a classe dominante não dependia apenas do poder coercitivo do aparelho de governo ou mesmo de seu poder econômico direto, mas que era por sua hegemonia, expressa na sociedade civil e no Estado, que os dominados eram persuadidos a aceitar seu sistema de crenças e compartilhar seus valores sociais, culturais e morais (idem, p. 117).

Assim, ao mesmo tempo em que confere ao Estado um poder muito maior do que o de funcionar como mero instrumento coercitivo, Gramsci alarga o escopo do que deve ser entendido por Estado, alargamento esse sem o qual, para ele, não se pode entender de que forma se dá efetivamente o processo da reprodução social capitalista.

Partindo de uma visão mais convencional, Offe (1984) elenca alguns elementos para a compreensão das funções estruturais do Estado capitalista. Segundo ele, a política econômica (a política pública em geral) tem um conteúdo eminentemente político, sendo suscetível à interferência das forças sociais, as quais recaem sobre uma instituição que já tem determinadas funções sociais. Para ele, a formação social capitalista e sua relação com o Estado podem ser descritas por meio de quatro determinantes estruturais que delimitam essas funções: a) $a$ privatização da produção - ao âmbito do Estado (ou seja, ao do setor público), em princípio, não estão associadas funções de produção material; portanto, em geral, há um impedimento (político) para que o Estado organize a produção segundo seus próprios critérios, já que a mesma é essencialmente privada; b) a dependência de impostos - o poder público depende, indiretamente, através dos mecanismos do sistema tributário, da acumulação privada; a implicação disto é que o poder do Estado é dependente desses recursos para seu orçamento, de modo que possa revelar seu poder também por meios materiais; c) a acumulação como ponto de referência - como o poder do Estado depende do processo de acumulação de capital, sem ser ele mesmo capaz de organizar este processo, o interesse supremo e 
mais geral dos que ocupam o aparelho de Estado consiste em assegurar condições que favoreçam o processo de acumulação privada, sendo que esta dependência não expressa qualquer aliança direta entre os ocupantes do poder de Estado e as classes sociais, nem o acesso privilegiado dos membros da classe capitalista aos centros de decisão do Estado (quando isto eventualmente ocorre não é causa, senão a consequência da dependência institucional estrutural da atividade pública em relação à acumulação); e d) a legitimação democrática - nas circunstâncias do sistema parlamentar-democrático, um partido ou coalizão política só obtém condições de assumir o poder de Estado quando consegue a maioria dos votos em eleições gerais, devendo, por isso, contar com o apoio do conjunto social, servindo de intermediário às reivindicações dos trabalhadores. (Offe, 1984, p. 123-124).

Assim colocadas, essas funções permitem deduzir uma dupla determinação do poder político a que está sujeito um Estado capitalista. Pela sua forma institucional, esse poder está determinado pelas regras de governo (democrático ou não) e, pelo seu conteúdo, esse poder está determinado pelo desenvolvimento e pelos requisitos do processo de acumulação de capital. Desta maneira, é possível definir a "política de Estado" como um conjunto de estratégias mediante as quais se produzem e reproduzem constantemente o acordo e a compatibilidade entre as quatro determinações estruturais, sendo que só existiria uma (e somente uma) estratégia geral de ação do Estado, qual seja a de criar as condições necessárias para incluir cada cidadão nas relações de intercâmbio, isto é, no mercado (idem, p. 125).

A discussão que Hirsch ([1994] 2007) estabelece com os teóricos da escola francesa da regulação é de escopo bem mais amplo que a de Offe, indicando o caráter complexo do processo de regulação social e apontando, em nosso entender, para uma síntese interpretativa do Estado e de seu lugar e papel no capitalismo contemporâneo.

Antes de refletir sobre sua visão é preciso lembrar que Hirsch, em sua formulação original - no contexto do debate marxista que ocorre nos anos 1970 vincula a política tão somente aos esforços da classe capitalista para usar o Estado a fim de neutralizar as crises econômicas. Todavia, mais recentemente, ele mesmo requalifica esta formulação a partir de um esforço crítico sobre a Escola da Regulação Francesa, constituindo-se no que poderia ser um complemento muito adequado aos aspectos tratados na primeira seção. Esta qualificação aproxima muito a posição de Hirsch de algumas teses de Gramsci e Offe, embora ainda se mantenham diferenças importantes, particularmente pela centralidade que o primeiro confere ao processo de acumulação de capital.

A referência original de Hirsch sobre a natureza do Estado capitalista aparece numa coletânea organizada por Holloway e Picciotto em 1978. Essa 
primeira aproximação é em parte crítica das posições tanto de Offe quanto de Gramsci, entre outros, em suas respectivas empreitadas para dar um sentido de objeto teórico ao Estado (ou ao político). Sua tese-força é então que o processo de acumulação de capital, construído a partir da propriedade privada, simultaneamente reproduz as suas precondições sociais, sem inicialmente requerer qualquer ajuda externa consciente, i.e., a intervenção do "político".

O conteúdo mais estrito do argumento pode ser assim apresentado. O processo de produção, governado pela lei do valor, reproduz simultaneamente, como processo de valorização, num movimento constantemente renovado, sua própria precondição social, inclusive suas relações de produção, sem inicialmente requerer qualquer intervenção externa consciente, i.e., intervenção política. As relações sociais básicas são sempre o produto histórico de leis objetivas que se afirmam através das ações individuais. Enquanto os aspectos essenciais da estrutura da forma capitalista de sociedade permanecerem intactos, essas leis têm um efeito determinante no processo de reprodução social. Isto significa que as estruturas sociais concretas, a relação mútua de classes, a forma dominante da divisão do trabalho, não podem ser submetidas a uma influência consciente, planejada - neste sentido política - e transformadas. Em outras palavras, as estruturas básicas e as leis de desenvolvimento da sociedade capitalista não são passíveis de serem "reguladas" politicamente. Em última instância, a organização consciente das relações sociais exigiria a abolição das relações capitalistas.

Nessa primeira formulação, para Hirsch, na sociedade capitalista, a apropriação do valor excedente e a preservação com coesão da estrutura social não dependem diretamente de relações de força, tampouco do poder e da força repressiva ideológicos. Todavia, como o processo de reprodução social e a apropriação do excedente são mediados pela livre circulação de mercadorias baseada no princípio da troca entre iguais, a abolição de todas as barreiras que estejam no caminho é um elemento essencial da ordem vigente. Neste sentido, instâncias que não sejam aquelas diretamente relacionadas ao processo privado de acumulação estariam submetidas ao seu desiderato (Hirsch, 1978, p. 61). O corolário dessa argumentação de Hirsch é que o Estado é parte de um processo de reprodução social que é essencialmente dirigido pelas leis da acumulação. Portanto, não faz nenhum sentido para ele que o Estado tenha algum tipo de movimento próprio ou autonomia diante do processo de acumulação. Ao contrário, entende que o Estado tem um caráter subordinado, sem com isto afirmar a tese de que ele esteja "a serviço" da classe dominante (já que isto implicaria uma regulação consciente das estruturas básicas da sociedade capitalista e uma menor importância e influência das leis objetivas que as produzem).

A formulação de Hirsch que até aqui resenhamos foi pensada num contexto de crítica a uma visão marxiana da sociedade capitalista que estaria sendo 
"esquecida". No contexto atual, em que ela se renova ([1994] 2007), o ponto é um pouco diferente, sobretudo considerando-se que a intenção é discutir criticamente a contribuição da Escola da Regulação. Nessa nova reflexão, Hirsch vai partir do princípio de que o Estado não é um fenômeno característico de todas as sociedades, ou seja, que, assim como a mercadoria, ele pertence a uma determinada formação histórica. Por isso, para ele, o político ("a forma política") deve ter sua gênese desvendada (tal como Marx o fez com a forma-valor), sendo esse déficit de teoria o problema maior e de fundo da teoria da regulação, tal como se encontra em seus teóricos iniciais (Aglietta, Boyer, Lipietz). Por conta disso, a visão de Estado que resulta dessa escola é, a um só tempo, estreita demais, como se ele fosse apenas mais um elemento da estrutura social ao qual são atribuídas funções, e larga demais, já que, por conta disso, se imagina que o poder do Estado, para monitorar as crises, por exemplo, é muito maior do que ele de fato é, pois o processo de regulação social não pode, para ele, ser reduzido à "atuação do Estado". Para Hirsch,

O Estado só pode se manter em sua particular determinação formal, enquanto estiver garantido o processo de reprodução econômica como processo de valorização do capital (...) ao mesmo tempo, a permanência do processo de reprodução econômica pressupõe a existência do Estado enquanto instância 'especial'. O Estado é necessariamente sempre um 'Estado intervencionista' no sentido mais amplo, mas sem se deixar confundir com a sociedade. 'Estado' e 'sociedade' não estão simplesmente separados, mas ao mesmo tempo unidos, e esta separação/união se realiza apoiada em conflitos sociais permanentes. Nesse sentido eles formam uma totalidade contraditória (2007, p. 21-22).

Assim, para Hirsch, os indivíduos da sociedade capitalista são, ao mesmo tempo, membros de uma classe e "sujeitos jurídicos civis formalmente livres e iguais" (idem, p. 22), sendo esta a contradição que move os processos e os conflitos sociais por meio dos quais o Estado se impõe e se mantém, mas que não podem ser reduzidos a ele. Daí também porque a suposta autonomia do Estado deva ser completamente relativizada. Na teoria convencional, considera-se o Estado como a única instituição responsável pelo bom andamento do sistema, já que o mercado é supostamente sempre virtuoso. Assim, o Estado deve dar conta de suas funções básicas, particularmente no que concerne à questão monetária, e garantir a vigência do quadro institucional legal necessário ao desenvolvimento capitalista, mas sem interferir e/ou afetar a eficiência dos mecanismos de mercado. Assim, em diversas circunstâncias históricas nas quais ocorrem problemas com o processo de acumulação, muitos deles intrínsecos, responsabiliza-se o Estado como se ele, de posse de sua plena autonomia, não estivesse cumprindo adequadamente as suas funções. De certo modo, o artigo de Hirsch (2007) aponta um viés semelhante também no campo crítico, embora, neste caso, as razões sejam outras. 
A regulação, portanto, não está limitada ao âmbito estatal, senão que ocorre socialmente por uma operação simultânea de/e entre diversas instituições. Há na verdade um "sistema de regulação" que consiste numa multiplicidade de instituições, organizações e conexões sociais:

A isto pertencem as empresas e suas federações, os sindicatos, a malha de organizações de interesse geral, as instituições de ensino, os meios de comunicação, o conjunto do aparato do "sistema político-administrativo" e, não por último, a família, como lugar de reprodução da força de trabalho. Ele compreende uma rede complexa de meios sociais, orientações culturais e 'mundos de vida' e é dominado, a um só tempo, pelas determinações formais contraditórias das relações de sociabilidade capitalistas (Hirsch, 2007, p. 53).

E todas as instituições regulativas estão impregnadas de maneira decisiva pela contradição entre a socialização "pelo mercado" e a socialização "de classe": as federações empresariais são ao mesmo tempo representantes "do" capital e associações de produtores privados concorrentes; os sindicatos são simultaneamente organizações (de parcelas) "da" classe operária e cartéis "voluntários" de oferta de força de trabalho de seus proprietários; a família é o lugar no qual, a um só tempo, são produzidas e reproduzidas as oposições de classe e onde se pode desenvolver a individualidade e a emoção, além de ser o local onde a socialização específica de gênero e a divisão do trabalho encontram a sua base (idem, ibidem).

Isto permite que os antagonismos sociais - não somente a oposição capitalista de classe, mas também de gênero e os antagonismos étnicos ou religiosos - possam ser compatíveis com a reprodução do conjunto das relações sociais. O modo de socialização capitalista, que tem no Estado uma 'instância especial', determina, de maneira essencial, a forma de expressão e a ligação desses antagonismos.

O que é importante resgatar do texto de Hirsch ([1994] 2007) é que as funções de regulação do Estado, para além de serem reais, não têm o alcance de regular o conjunto social, nem tampouco o conjunto da economia. Isto, de algum modo, altera o que formula Offe (1984), pois requalifica o papel social do Estado. Sendo assim, não é lícito atribuir ao Estado responsabilidades que ultrapassam sua capacidade e escopo de ação e, quando isto ocorre, suas razões são de cunho inteiramente ideológico, visto que, regra geral, considera-se que o Estado extrapolou suas funções e interferiu indevidamente na "regulação" que o próprio mercado é capaz de produzir.

Hirsch, ainda como reflexo do debate sobre a "derivação do Estado" ocorrido ao final dos anos 1970, vai afirmar que a aparente separação entre 'política' e 'economia' (necessária para legitimar o processo de extração do 
excedente numa sociedade onde as relações materiais são todas indiretas, já que mediadas pela mercadoria) ${ }^{22}$, não permite concluir que a forma política possa ser "derivada" da estrutura econômica, pois a economia não está pressuposta à política nem teórica nem historicamente e o Estado não é, portanto, "nenhuma superestrutura que possa ser explicada em relação à base econômica" (Hirsch, 2007, p. 19). Tal posição, em princípio, afastaria completamente a visão de Hirsch daquela de Gramsci, visto que este último coloca o Estado explicitamente no plano da superestrutura. Contudo, se lembrarmos que para Gramsci o conceito de Estado que importa é muito mais amplo, englobando a própria sociedade civil, e que, além disso, na visão gramsciana, as superestruturas ideológicas têm primazia perante a estrutura econômica, então a distância entre os dois autores, pelo menos neste aspecto, pode ser considerada como meramente semântica ${ }^{23}$.

Cabe registrar, mais uma vez, que a atribuição ao Estado da responsabilidade pelo processo inteiro de regulação social não é característica apenas dos defensores da "regulação de mercado", mas está presente também no campo crítico. Também neste caso prevalecem razões ideológicas, só que direcionadas para uma superação da ordem social vigente.

Isto nos leva mais uma vez à crítica feita por Hirsch aos teóricos da regulação. Ela não se constrói por uma negação da ideia da regulação como um processo central ao desenvolvimento capitalista, tampouco pela afirmação que os mesmos fazem de que o processo em questão não é inercial. A crítica é teórica, centrada na incapacidade que teria essa escola de formular seus conceitos "sem um sujeito dirigente determinante" do processo de desenvolvimento. É aí que o Estado passaria a assumir uma condição incompatível com os fundamentos teóricos dessa escola, talvez por uma imposição do debate histórico do qual os regulacionistas foram obrigados a participar (vide nota 2). É como se a atribuição que o campo dominante confere ao Estado se impusesse também ao terreno do debate crítico.

Passemos agora a um esforço de síntese dos elementos teóricos apresentados.

(22) Como a troca requer, por definição, que os agentes que a operam o façam voluntariamente, a classe dominante é como que obrigada a renunciar ao uso direto dos meios de coação física, que encontram uma forma institucional separada de todas as classes sociais por meio da formação do Estado. Daí a necessária separação entre política e economia, entre Estado e sociedade. Mas daí também a "seletividade estrutural" das instituições políticas em relação aos diferentes grupos e classes, que confere ao Estado seu caráter classista sem que ele resulte da intenção consciente dos atores.

(23) Outro elemento da análise de Hirsch que parece confirmar essa proximidade é sua consideração de que a forma política não se confunde com o aparelho de Estado, mas se realiza num contexto complexo de instituições que engloba, entre outros, partidos, federações, meios de comunicação de massa, empresas privadas, associações e famílias (Hirsch, 2007, p. 35). 


\section{Espoliação e regulação no capitalismo financeirizado}

Como já indicamos na introdução, entendemos a formulação do capitalismo contemporâneo de David Harvey como sustentada em duas determinações. A primeira tem que ver com a lógica privada de acumulação, ou aquilo que ele chama de processo molecular de acumulação de capital. Já a segunda, assentada na lógica territorial, assume, para nós, a feição de regulação social, operada pelo Estado, o que aproxima Harvey da forma de abordagem das assim chamadas teorias da regulação.

Sobre a primeira dessas lógicas, o que há de novo na fase atual é que há uma crescente financeirização do processo de acumulação. Nos termos apresentados por Chesnais, isto significa que o movimento do dinheiro, mais especificamente, do capital portador de juros, ganha não só autonomia, mas também submete o processo produtivo à sua lógica. Harvey reporta a mesma influência do capital financeiro sobre o processo de acumulação, porém não o faz com a radicalidade de Chesnais, que virtualmente o toma como um processo inovador, capaz de alterar a essência mesma do sistema. Essa radicalidade se deve à sua filiação à escola da regulação, já que, em sua interpretação, um novo regime de acumulação foi instaurado e esse novo regime, centrado na acumulação financeira, teria engendrado um novo modo de regulação, configurando um quadro inédito na história capitalista.

Para Harvey, ao contrário, no capitalismo atual, o processo de financeirização aprimora e aprofunda uma característica que lhe seria constitutiva, qual seja, sua tendência a espoliar. Tudo se passa como se o "algo fora de si mesmo", com o qual o capitalismo tem sempre que contar para que o "motor da acumulação não pare de repente" ${ }^{24}$, tenha se tornado agora a regra do sistema. Com isso, a segunda das lógicas, por ele indicada, a do território, ganha uma feição ainda mais capitalista, já que a acumulação por espoliação requer o Estado como elemento ativo do processo, pois só assim as ordenações espaço-temporais, sempre presentes na atividade da acumulação, podem adquirir o caráter espoliador requerido ${ }^{25}$.

(24) É o próprio Harvey quem resgata essa forma de expressão, muito apropriada, cunhada por Hanna Arendt em seu livro sobre o imperialismo.

(25) Se a espoliação não é tão visível quanto poderia, isso se deve ao fato de a valorização fictícia, que corresponde a uma parcela significativa dos expedientes espoliadores no capitalismo de hoje, ter a forma do capital, ou seja, do movimento "normal" da acumulação. Assim, apesar de depender crucialmente do Estado para pôr em marcha seu séquito de fraudes e empulhações, ela não chega a requerer, como foi o caso nos processos originários de acumulação primitiva, um estado absoluto e com poderes discricionários (já que, afinal de contas, o sistema financeiro é parte natural do sistema). O mesmo não pode ser dito, por exemplo, de outros processos espoliadores, também mencionados por Harvey, como as privatizações. Basta lembrar da recente história das privatizações em nosso país, para que fique patente a necessidade de o Estado fazer uso de seu poder discricionário. 
A partir da interpretação de Harvey, podemos também dizer que o sistema é portador de uma instabilidade que é estrutural (porque seu sucesso não depende só de seu automatismo, mas também da permanente disponibilidade de mecanismos externos, cujo arbítrio ele não detém inteiramente) e essa instabilidade se transforma em fragilidade sistêmica quando o capital financeiro está no comando do processo. A utilização desses dois últimos termos instabilidade estrutural e fragilidade sistêmica - não é casual. É Chesnais (2005) quem faz a distinção, buscando afirmar o caráter inédito desta fase da história capitalista. Nos termos da aproximação entre as diferentes visões aqui proposta, consideramos que a instabilidade tem que ver com a ordem social, vale dizer, com a característica de que o processo de produção material é intrinsecamente privado, como nos aponta Claus Offe, interpretação que também não é estranha à primeira formulação de Hirsch (1978), quando o Estado foi visto tão somente como um expediente a ser utilizado pela classe capitalista para enfrentar a tendência decrescente da taxa de lucro. A fragilidade, por outro lado, tem que ver com as características que fazem com que o processo de acumulação contemporâneo possa eventualmente ser até mais dinâmico, pela amplitude dos mecanismos de alavancagem que estão disponíveis às unidades de capital, mas com a geração de crises frequentes e profundas como sua característica mais marcante, o que o coloca numa situação de risco sistêmico permanente. Nos termos de Harvey, isso significa que a financeirização funciona como um remédio para a sobreacumulação, que, tal como uma droga que causa dependência, só melhora o estado do doente porque o agrava cada vez mais. Sendo assim, parece lícito considerar que a violência envolvida nos processos de acumulação tornar-se-á cada vez mais profunda, exigindo cada vez mais do processo inteiro de regulação social para que as crises sejam evitadas.

É a consideração desse quadro que obriga a uma reflexão mais profunda sobre a complexa dinâmica existente entre o Estado, enquanto instância "separada" de constituição do poder e da hegemonia da classe dominante, e o sistema de regulação como um todo. Por isso, o recurso às formulações envolvidas no âmbito do debate sobre as teorias de Estado fez-se necessário, com o que se enriquece a análise e se amplia o conjunto dos elementos que podem caracterizar o capitalismo contemporâneo.

Sustentamos, a partir de Holloway e Picciotto (1978) ${ }^{26}$ e Carnoy (1988), que o campo da política ou da teoria do Estado capitalista é sujeito a polêmicas teóricas ainda não resolvidas. Por isto, é um campo de discussão em que é preciso

(26) Aqui nos referimos ao texto feito pelos dois autores na Introdução, que consiste, na verdade, num artigo- resenha das questões postas pelos textos selecionados para o livro. Esta introdução é recorrentemente citada na bibliografia especializada, por sua capacidade de sistematizar aspectos centrais do debate a respeito do Estado. 
fazer opções teóricas a partir das exigências da análise. Sugerimos que um possível desenvolvimento do campo político compatível e complementar ao de David Harvey é o de Hirsch ([1994]2007). Neste, há não apenas uma avaliação crítica da Escola da Regulação Francesa, mas também um aprofundamento a respeito da natureza do processo de regulação social contemporâneo.

Ademais, para Hirsch ([1994]2007, p. 53) há efetivamente um "sistema de regulação" mais amplo do que o Estado. Sugerimos que o "sistema de regulação" converge, sem identificar-se, com o que Harvey apontou como sendo "estruturas de poder independentes do Estado" (Harvey, 2004, p. 80). Para Harvey a regulação que ocorre fora do âmbito do Estado está direta e inteiramente submetida à lógica molecular da acumulação de capital (o que requer a interferência do Estado, mesmo que isso não seja diretamente admitido). Conforme já antecipado, aí estão basicamente as redes e estruturas de operação do capital, incluindo o parentesco, as diásporas, os vínculos religiosos e étnicos, e os códigos lingüísticos. De maneira semelhante, o "sistema de regulação" de Hirsch consiste em uma multiplicidade de instituições, organizações e conexões sociais. Nele estão, entre outros, as organizações de interesse geral, os sindicatos de trabalhadores e as associações empresariais, o aparato do sistema políticoadministrativo, os meios de comunicação e as famílias, sendo toda essa complexa rede dominada pelas determinações contraditórias da sociabilidade capitalista. Assim, também em Hirsch, aparece com destaque a importância das redes de relações sociais na regulação e, portanto, na reprodução total do sistema, porém depreende-se que aí o controle não é tão direto quanto a proposição de Harvey parece indicar. Nem todas as redes estão necessariamente subordinadas de modo direto ao movimento da acumulação, e elas podem estabelecer relações contraditórias com aspectos e elementos que também não estão diretamente submetidos a esse processo. Exemplos importantes dessa diferença são as menções que faz Hirsch às instituições de ensino e à família.

Esses são elementos de uma discussão que normalmente se refere ao campo político de disputa da hegemonia social, conforme nos informa Gramsci. Este campo parece mais complexo do que a análise de Harvey nos sugere. Por exemplo, as inovações produtivas, que são a base do processo de acumulação da fase atual do capitalismo permitiram efetivamente, como quer Harvey (1992), uma conexão muito maior e mais potente entre os mecanismos ideológicos de reprodução da cultura capitalista. Contudo, assiste-se também, entre outros elementos contraditórios, à revitalização de movimentos sociais de preservação das culturas regionais originárias, o que demonstra que é preciso alargar o escopo da análise de modo a entender a lógica territorial a que se refere Harvey, não só como uma lógica mediada pelo poder político do Estado, mas como uma lógica também eivada, ela mesma, de contradições que decorrem do complexo de "meios 
sociais, orientações culturais e mundos de vida" também presentes, direta ou indiretamente, no processo de regulação social, tal como entendido por Hirsch. Essas contradições limitam o poder de ação do Estado enquanto instância fiadora da produção e reprodução da dominação capitalista.

Assim, se é verdade, como quer Harvey, que a atual fase capitalista tem visto a mudança de ênfase passar da acumulação ampliada para a acumulação por espoliação (com ênfase nos expedientes de valorização financeira e fíctícia), estando esta última no cerne das práticas imperialistas, portanto, no âmbito do poder político e da atuação do Estado, também é verdade que este imperialismo, que, como demonstra o próprio Harvey, caminha agora a reboque do processo de acumulação, tem de se ver, por isso, com as contradições que emanam da complexidade do processo total de regulação social.

Sugerimos, por isso, que a tese de David Harvey sobre o capitalismo contemporâneo (que envolve, mas não se reduz às teses da financeirização de Chesnais), ampliada por uma discussão mais profunda do campo político, seja no âmbito nacional (do Estado), seja no âmbito internacional (macroestrutural, da política supranacional), constitui-se na formulação, com maior capacidade de tradução, das condições históricas em que vivemos.

Assim, por exemplo, a crise atualmente experimentada apresenta-se como crise do processo como um todo de regulação do capitalismo. Ela reflete uma incapacidade geral dos mecanismos de regulação (que envolvem, mas extrapolam o âmbito do Estado) não só de interferir em favor de ordenações espaço-temporais não deletérias, mas também de perpetuar os outros mecanismos (espoliadores) que têm aliviado a sobreacumulação crônica de que padece o sistema.

Pelo que vimos de considerar, os efeitos sistêmicos da crise são incontroláveis porque alcançam os "sistemas de regulação social", que são intrinsecamente nacionais ${ }^{27}$. A "globalização", contraditoriamente, aguçou as forças que atuam privilegiadamente no âmbito das sociedades nacionais, tensionando o "campo político", particularmente num momento em que as ordenações espaço-temporais necessárias para enfrentar o problema da sobreacumulação operam de forma destrutiva e exacerbam a acumulação por espoliação. As razões desse tensionamento são múltiplas, indo desde a imposição de políticas econômicas padrão até a proposição de uma lógica internacionalista homogeneizadora da "cultura ocidental". Assim, se a crise atual tem origem razoavelmente bem definida (uma pane nos mecanismos de valorização financeira que apareceu enquanto crise do mercado imobiliário americano), sua extensão e profundidade ainda estão em aberto e isto não só por conta dos desdobramentos

(27) A segunda rodada dessa crise (2010), da qual são vítimas alguns países da zona do euro, é indicativa, principalmente pelos seus desdobramentos político-sociais, desse caráter.

Economia e Sociedade, Campinas, v. 20, n. 2 (42), p. 243-272, ago. 2011. 
stricto-sensu econômicos que ela ainda vai gerar, mas principalmente pela probabilidade de que ela requeira uma transformação geral nos mecanismos e processos de regulação social, que vai muito além dos expedientes regulatórios disponíveis aos estados nacionais. Resta saber que grau de violência doméstica e imperialista será necessária para efetivar essa transformação.

\section{Referências bibliográficas}

AGAMBEN, G. Estado de exceção. São Paulo: Boitempo, 2004. . Le capitalisme de demain. Notes de la Fondation Saint-Simon. Nov. 2004. . La fin des devises clés. Paris: La Decouverte, 1986.

; ORLEANS, A.; OUDIZ, G. Contraintes de change et regulations macroéconomiques nationales. Recherches Economiques de Louvain, v. 46, n. 3, p. 175206, set. 1980.

ARENTI, W. L. Teorias da regulação capitalista, objeto e método: além do economicismo, estruturalismo e funcionalismo. Textos de Economia, Florianópolis, v. 9, n. 1, p. 38-60, jan./jun. 2006.

AUGUSTO, A. G. Fundamentos metodológicos da abordagem da regulação: origem histórica e questões fundadoras. Ensaios FEE, Porto Alegre. v. 25, n. 2, p. 427-442, out. 2004.

BERCOVICI, G. Constituição e Estado de exceção permanente - A atualidade de Weimar. São Paulo: Azougue Editorial, 2004.

BOYER, R. A teoria da regulação - uma análise crítica. São Paulo: Nobel, [1986] 1990.

Formes d'organisation implicites à la théorie générale. Une interprétation de l'essor puis de la crise des politiques économiques keynésiennes. In: BARRÉRE, A. (Ed.). Keynes aujourd'hui: théories et politiques. Paris: Economica, 1985. p. 541-559.

BRAGA, J. C. de S. Temporalidade da riqueza - Uma contribuição à teoria da dinâmica capitalista. Tese (Doutorado)-Instituto de Economia da Universidade Estadual de Campinas, 1985.

. A financeirização da riqueza - a macroestrutura financeira e a nova dinâmica dos capitalismos centrais. Economia e Sociedade, Campinas, n. 2, 1993.

BRENNER, R. The economics of global turbulence: a special report on the world economy 1950-1998. New Left Review, n. 229, May 1998.

. O boom e a bolha. Rio de Janeiro: Record, [2002] 2003.

BRUNO, M. A. P. Crescimento econômico, mudanças estruturais e distribuição: as transformações do regime de acumulação no Brasil. Tese (Doutorado)-Universidade Federal do Rio de Janeiro/UFRJ, 2005.

CARNOY, M. Estado e teoria política. 2. ed. Campinas: Papirus, [1984] 1988. 
CEPAL. Globalização e desenvolvimento. Santiago: 2002.

CHESNAIS, F. Mundialização financeira e vulnerabilidade sistêmica. In: CHESNAIS, F. (Org.). A mundialização financeira. São Paulo: Xamã, 1998.

. O capital portador de juros: acumulação, internacionalização, efeitos econômicos e políticos. In: CHESNAIS, F. (Org.). Finança mundializada. São Paulo: Boitempo, 2005.

CONCEIÇÃO, O. A. C. Crise e regulação: metamorfose restauradora da reprodução capitalista. Ensaios FEE, Porto Alegre. v. 8, n. 1, p. 155-74, 1987.

- Instituições, crescimento e mudança na ótica institucionalista. 1. ed. Porto Alegre: Fundação de Economia e Estatística, 2002. 228p.

FARIA, L. A. E. A economia política, seu método e a teoria da regulação. Ensaios FEE, Porto Alegre . v. 13, n. 1, p. 268-290, 1992.

- As formas institucionais da estrutura: do micro ao macro na Teoria da Regulação. Ensaios FEE, Porto Alegre.v. 22, n. 1, p. 187-204, 2001.

GRAMSCI, A. Cadernos do Cárcere. Rio de Janeiro: Civilização Brasileira, 2007. 6v.

HARVEY, D. Spaces of capital: towards a critical geography. New York: Routledge, 2001.

. O novo imperialismo. São Paulo: Edições Loyola, 2004.

. Limits to capital. London: Verso, [1982] 2006.

. A condição pós-moderna. São Paulo: Edições Loyola, [1989]1992.

HIRSCH, J. Forma política, instituições políticas e Estado. Crítica Marxista, n. 24 / 25 (publicado em duas partes), p. 9-36 e p. 47-73. [1994] 2007.

- The State apparatus and social reproduction: elements of a theory of the bourgeois State. In: HOLLOWAY, J.; PICCIOTTO, S. State and capital: a Marxist debate. London: Edward Arnold (publishers) Ltd., 1978. p. 57-107.

HOLLOWAY, J.; PICCIOTTO, S. State and capital: a Marxist debate. London: Edward Arnold (publishers) Ltd., 1978.

JESSOP, B. Regulation theory in retrospect and prospect. Economy and Society. Abingdon/UK, v. 19, n. 2, p. 153-216, 1990.

LIPIETZ, A. Crise et inflation, pourquoi? Paris: Maspero, 1979.

Le monde enchanté. De la valeur à l'envol inflacioniste. Paris: La DecouverteMaspero, 1983.

LUXEMBURGO, R. Acumulação de capital. São Paulo: Abril Cultural, 1985.

MIZRUCHI, M. S. Berle and Means revisited: the governance and power of large U.S. corporations. University of Michigan, Apr. 2004. Disponível em: $<\underline{\text { http://www- }}$ personal.umich.edu/ mizruchi/tsweb.pdf>. Acesso em: 2004. 
Niemeyer Almeida Filho / Leda Maria Paulani

O'CONNOR, J. The fiscal crisis of the State. New York: St. Martin Press, 1973.

OFFE, C. Problemas estruturais do Estado capitalista. Rio de Janeiro: Tempo Brasileiro, 1984.

PAULANI, L. M. Brasil delivery. São Paulo: Boitempo, 2008.

POSTONE, M. Teorizando o mundo contemporâneo: Robert Brenner, Giovanni Arrighi, David Harvey. Novos Estudos Cebrap, São Paulo, n. 81, jul. 2008.

PRADO, E. F. S. Desmedida do valor. São Paulo: Xamã, 2005. 